\title{
Ability grouping: Year group differences in self concept and attitudes of secondary school pupils
}

Susan Hallam and Kim Deathe, Institute of Education, University of London

Contact Susan Hallam, Institute of Education, University of London, 20 Bedford Way, London, WC1H OAA

E-mail s.hallam@ioe.ac.uk

Phone 02076126371 


\title{
Ability grouping: Year group differences in self concept and attitudes of secondary school pupils
}

\begin{abstract}
The vast international literature on the effects of different types of ability grouping on selfconcept and pupils' attitudes towards school has focused on pupils from single year groups. This paper aimed to explore year group differences in pupils' self concept and attitudes towards school as influenced by ability grouping. The study was cross sectional in design and measured attitudes towards school and mathematics; mathematics, general and school selfconcept and preferences for different kinds of grouping in 234 students from years 7 through 10 attending a mixed comprehensive school. The findings indicated that mathematics self concept was consistently lower than school and general self concept; all aspects of self concept increased up to year 9 and then declined in year 10; pupils in the higher sets tended to have higher self concepts; pupil preferences for setting were greater in the higher year groups, as was the extent to which the top set was perceived to be the best. A substantial proportion of pupils wanted to move set, usually to a higher set. Set placement itself did not appear to have a consistent effect on attitudes towards mathematics. This seemed to be mediated by the quality of teaching.
\end{abstract}




\section{Ability grouping: Year group differences in self concept and attitudes of secondary school pupils}

\section{Introduction}

In the UK, current pressure to raise attainment has led many schools to follow government guidelines (DfEE, 1997) and adopt structured ability grouping practices, in particular setting (when pupils are grouped by ability across classes for particular subjects). There is an extensive international literature on ability grouping (for reviews see Hallam \& Toutounji, 1996; Harlen \& Malcolm, 1997; Ireson \& Hallam, 1999; Sukhnanden and Lee, 1998; Hallam, in press) which indicates that the effects of ability grouping on attainment are not consistent. The most recent UK research at secondary level (Ireson et al, in press), found an effect of setting on progress in mathematics, but not in English or science. In mathematics, pupils attaining higher levels in national tests at age 11 made more progress in sets, whereas lower attaining pupils made more progress in mixed ability classes (Ireson et al., in press). While the effects of structured grouping on attainment are equivocal, there is evidence that where structured systems are in operation those in the lower sets are stigmatized (Hargreaves, 1967; Ball, 1981; Hallam et al., submitted, a, b). There may also be an adverse impact on pupils' self esteem, self-concept and their attitudes towards school and schoolwork (Gamoran \& Berends, 1987; Lacey, 1974; Oakes, 1985). Oakes (1985) has argued that for students in low ability groups, the self-concept becomes more negative as they progress through school. However, not all the evidence supports this. Kulik \& Kulik (1992) found that ability grouping tended to 
raise the self-esteem scores of lower aptitude students and reduce the self-esteem of higher aptitude students.

These mixed findings, in part, may be the result of the different measuring instruments used in the research but also mediating factors within the school, for instance, ethos, the quality of the teaching and teachers' attitudes towards low and high attaining pupils. In addition, self-esteem is not a single entity. General measures of self-concept are only weakly correlated with academic attainment. Self-concept scales which more specifically relate to curriculum areas tend to be more closely related to attainment (Marsh, Parker \& Barnes, 1985; Marsh \& Yeung, 1997). The average level of attainment in the school may also influence self-concept, so that pupils in schools with higher average levels of attainment have lower academic self-concepts than pupils of similar ability in schools with lower average attainment (Marsh, 1991; Marsh \& Rowe, 1996). These effects may be stronger in highly competitive and structured settings where students follow a fixed curriculum and are assessed in comparison with others (Marsh \& Peart, 1988). Pupils who participate in programmes for the gifted and talented tend to experience a decline in self-concept supporting this theoretical position (Marsh, Chessor et al (1995). Ability grouping affects class composition providing an immediate working environment where comparisons with others are within a relatively small attainment span. At the same time, it provides pupils with hard evidence regarding their place in the academic pecking order as perceived by influential others, i.e. teachers. This is likely to have substantive effects on pupils' self-perceptions in relation to the academic domain where the ability grouping is adopted unless teachers within the school take action to ameliorate the effects. If ability grouping occurs in a great many subjects, pupils' overall school self-concept is likely to 
be affected. There is some support for this (Ireson et al., 2001). Pupils' general self-concept was higher in schools with moderate levels of setting as opposed to schools with high or very low levels. However, the degree of setting in mathematics and science had no effect on the corresponding academic self-concepts, although in English setting tended to lower the selfconcepts of the higher attaining pupils and raise the self-concepts of lower attaining pupils. This suggests that complex interactions are in operation which mediate grouping effects on self-concept and may lead to different outcomes for low and high ability pupils in different schools.

Recently in the UK, several studies have explored pupils' experiences of different types of ability grouping. This approach has been exemplified by the work of Boaler (1997a; 1997b; 1997c; Boaler et al., 2000) who researched the experiences of pupils studying mathematics in two contrasting grouping systems, mixed ability and setted. In research based on classroom observation and interviews with students, Boaler outlined how many of the students in the schools where setting was adopted for mathematics faced negative consequences as a result. Eighty three percent of the students interviewed in the setted classes wanted either to return to mixed ability teaching or to change set. This dissatisfaction was not restricted to those in the lower sets. Some of the students taught in the highest sets (Boaler 1997b) felt disadvantaged because they found it difficult to cope with the fast pace of the lessons and the pressures of consistently working at a high level. Particularly vulnerable were girls who wanted to acquire a deep understanding of mathematics who found this impossible in an environment where the pace of work did not allow for time for consolidation. These girls reported wanting to move to 
a lower set. The boys also reported adverse effects of the pressure in the higher sets, but they did not wish to move to a lower set (Boaler et al, 2000).

A larger scale UK study exploring pupils' experiences of ability grouping has shown that pupils tend to be accepting of the grouping structures operating within their school, although having experienced setting there was a tendency to prefer it to mixed ability teaching (Hallam et al., submitted, b). This overall trend was overlaid by gender, set placement and socioeconomic status factors. Boys, those of low socio-economic status and those in the lowest sets tended to prefer mixed ability teaching (Hallam et al., submitted, b). The evidence suggested that a significant proportion of pupils were unhappy with their set placement. Most wanted to change sets in an upward direction to be given harder work, improve their prospects in examinations and their careers, and their status within school. A small number of pupils wished to move down a set to improve their understanding and receive work which they perceived to be better suited to their needs. Overall, pupils in lower sets tended to have less positive relationships with their school (Ireson and Hallam, 2001) and there was a tendency for those in the top and bottom sets to experience some stigmatization as a result of their set placement (Hallam et al., submitted a, b). However, within these overall trends, there were substantial differences between the experiences of pupils in individual schools (Ireson and Hallam, 2001).

Much recent research, in considering these issues, has done so in relation to single cohorts of pupils. It has not explored differences in self-concept and attitudes of pupils at different stages in their schooling as they experience increasing levels of structured ability grouping. The 
research described here is small scale, undertaken within a single school, adopts a cross sectional approach and focuses on setting in mathematics. It aims to explore differences in aspects of self-concept and attitudes of pupils in different year groups as they encounter increasing levels of structured ability grouping.

\section{Method}

The participants in the study were 234 students from years 7-10 (aged 11 to 15) of a mixed comprehensive school. The pupils were taught mathematics in year 7 (aged 11/12) in mixed ability groups. In year 8 (aged 12/13) they were differentiated by ability into two parallel bands (structures which divided the pupils into two groups of classes undifferentiated by ability) which were then setted (pupils were grouped by ability for different subjects across classes within the bands). In year 9 (aged13/14) the students were set into ability groups across the whole year group with several parallel sets. In year 10 (aged 14/15) the setting procedure became more highly differentiated with the year group being divided into nine sets. Movement between sets at this stage was rare. The setting in years 8 and 9 was determined by teacher assessment of class work and internal results. In year 10, class work, internal and national test scores were taken into account. For the purposes of some of the analysis in the study, parallel sets were combined to give 4 ability groups in years 8 and 9 and 5 in year 10. For the purposes of making comparisons across year groups the pupils were divided into three groups, top set, middle sets and bottom set. 
Two tutor groups from each year group completed a questionnaire which included the maths self-concept, general self-concept and general school concept from the SDQ II scale (Marsh, 1990) and statements relating to attitudes towards school and mathematics, perceptions of setting and support from teachers. The items in the questionnaire were adapted from those used in the larger study exploring pupils experiences of ability grouping described above (Hallam et al, submitted b; Ireson et al, 2001). Questions 1-30 comprised the measures of Maths Self-concept, General Self-concept and General School Self-concept from the SDQ II questionnaire, (Marsh, 1990). Questions 31-72 related to attitudes towards mathematics and school, experiences of ability grouping and perceptions of teacher skills.

The Marsh SDQII questionnaire utilizes a six point rating scale. Pupils express whether statements are true, mostly true, more true than false, more false than true, mostly false and false. The statements relate to Mathematics Self- concept, e.g. I enjoy studying mathematics, I have trouble understanding anything with mathematics in it; School Self- concept, e.g. I do well in tests in most school subjects, I get bad marks in most school subjects; and General Self -concept, e.g. Overall, most things I do turn out right; I can do things as well as most people.

The remainder of the questionnaire explored attitudes towards school, setting, mathematics and perceptions of mathematics teachers. Some elements were based on 5 point rating scales. For instance pupils responded from always to never in relation to statements such as: The work I do in maths is interesting for me; My maths teachers take the time to explain things; I'm bored in maths lessons. Other statements required responses ranging from strongly agree 
to strongly disagree, e.g. I am very happy when I am at school; School work is worth doing. For some statements pupils were asked to make choices between responses, e.g. Which type of grouping do you think is best, mixed ability, sets, streams, bands, other, don't know? In other cases yes/no responses were followed by an open question, e.g. Would you like to be in a different set? If so, why?

The questionnaire was administered to each tutor group over a period of two weeks, each group being subjected to the same procedure. The instructions on the front page of the questionnaire were read out verbatim, with an example written on the white board. The questionnaire was administered to 8 pupils with Special Educational Needs in two small groups.

The data were entered into SPSS (Statistical Package for the Social Sciences) and the three elements of the Marsh SDQII calculated. Composite scores were also calculated for attitude towards school, attitude towards set and perceptions of teacher skills. The data were analysed using Analysis of Variance techniques to explore differences in scores between year groups and Multiple Regression to predict aspects of the self-concept.

\section{Findings}

\section{Changes in aspects of self-concept as pupils progress through school}

The mean scores for mathematics self-concept increased from 37.67 in Year 7 to 40.34 in 
Year 9 falling to 37.26 in Year 10. These differences were statistically significant $(\mathrm{F}=2.748$, $\mathrm{df}=3, \mathrm{p}=.044)$.

This pattern was repeated for general school concept and general self-concept In year 7 the mean for general school concept was 44.9 increasing to 48.68 in year 9 . There was a subsequent drop to 43.05 in year 10 . These differences were statistically significant $(\mathrm{F}=4.51$,

$\mathrm{df}=3, \mathrm{p}=.004)$. General self-concept rose from 46.67 in year 7 , to 49.98 in year 9 falling to 45.49 in year 10 . These differences were significantly different $(\mathrm{F}=3.7, \mathrm{df}=3, \mathrm{p}=.012)$. Figure 1 graphically demonstrates the changes.

\section{Figure 1 about here}

\section{Differences between ability groups within year groups}

There were no significant differences in any of the measures of self-concept between the two mixed ability mathematics groups in year 7 .

In year 8, there were significant differences between the responses of pupils in different sets to statements included in measures of general school self-concept and general self-concept. Those in the top sets demonstrated higher self-concepts (see Table 1). This pattern was repeated in year 9. Those in the top sets had consistently higher scores on all measures. In the lower sets the pattern was less clear (see Table 2). 
In year 10 mathematics self-concept was clearly differentiated by set (see Table 3) but students in the middle sets scored higher on school and general self concept.

Generally, the mean results for each year group declined in relation to the ability group which the pupils were in. In the lower ability range the lowest two sets consistently produced the lowest mean scores for all aspects of self-concept.

\section{Tables 1, 2 and 3 about here}

\section{Pupils perceptions of the best method of grouping}

Overall, the pupils' perceptions of the best method of grouping changed in relation to year group as experiences of different types of grouping increased. In Year 7, there was virtually no difference between those selecting mixed ability teaching and setting $(38 \%, 37 \%)$ as the best method of grouping. By year 8 this had changed, $63 \%$ preferring setting. This preference continued to increase until by year 10 it was $83 \%$. Table 4 provides the details.

\section{Table 4 about here}

When analysis was undertaken examining setting preferences by year group and set 
placement, the majority still preferred setting but there were considerable differences. In year 8 , only $59 \%$ of set three preferred setting as opposed to $80 \%$ in the top set and $90 \%$ in the $2^{\text {nd }}$ set. In the bottom set only $15 \%$ preferred setting, $46 \%$ said that they didn't know. In year 9 , only 57\% of set 4 preferred setting, although by Year 10 of those in set 5, 88\% said that they preferred setting (see Table 5 for details).

\section{Table 5 about here}

\section{Pupils' perceptions of the best set}

In year 7 most pupils did not respond to the question 'which is the best set?', as there was no setting in this year group. In all the year groups where setting was in operation, overall the top set was seen as best. In year 8 the percentage was $68 \%$ falling to $55 \%$ in year 9 rising to $60 \%$ in year 10. In year 9 there was an increase in the preference for set 2 (see Table 6 for details)

\section{Table 6 about here}

\section{Reasons for choice of best set}

The pupils were asked to provide reasons for their choice of best set. $27 \%$ of the cohort responded. Seven reasons were given for choosing set 1 as the best set. The most frequently cited related to perceptions that those in the top set were intelligent (49\%). Students also frequently acknowledged that being in the top set meant attaining at a high level (19\%). Other 
reasons included being given work at an appropriate level, having the respect of peers, having the best teacher, having the best opportunities and working at a faster rate.

\section{Satisfaction with set placement}

Overall, seventy two percent of pupils were happy with their set placement. In year 7, 88\% did not want to change class. In year 8 , the percentage who were happy with their set placement was $67 \%$. This figure remained fairly consistent in years 9 (68\%) and $10(66 \%)$. Of those wanting to change set, $84 \%$ wanted to move to a higher set and $11 \%$ to a lower set.

\section{Reasons for wanting to change set across year group}

Overall. twenty three percent of the sample wanted to move to a higher set. The most frequently given reason (44\%) for this was because the work was too easy. Other reasons included to be with friends, to gain respect from peers, to get better marks, as a reward for effort, to take a higher tier examination paper, to have a different teacher, to learn more, and to get a better job. Only $3 \%$ of the sample wanted to move to a lower set. The reasons given for wishing to do so were that the work in their current set was too difficult and that they thought that they would learn more in a lower set.

\section{Relationships between ability grouping and attitudes towards school}

A composite attitude towards school score was calculated. A multivariate analysis of variance 
showed no significant differences between attitudes to school between year groups, but a significant effect of setting $(\mathrm{F}=3.18, \mathrm{df}=2, \mathrm{p}=.04)$. Dividing the sets into top, middle and bottom to enable comparisons to be made across year groups, the overall means were 22.81 for the top set, 22.6 for the middle sets and 20.6 for the bottom sets.

\section{Relationships between ability grouping and pupils' attitudes towards mathematics lessons}

A composite attitude towards mathematics score was calculated. There were no significant differences in attitudes towards mathematics between year groups but there were significant differences between those in high, middle and low sets $(\mathrm{F}=5.36, \mathrm{df}=2, \mathrm{p}=.005)$. The pattern of scores was similar those for attitudes towards school. Those in the top set had the most positive attitudes with a mean of 10.6 those in the middle sets 9.9 and those in the bottom set 9.35 .

\section{Attitude to the set that I am in}

A composite attitude towards the set that I am in was calculated. There were no significant differences in attitude towards set between those in different year groups. There was an almost significant effect of set $(\mathrm{F}=2.96, \mathrm{df}=2, \mathrm{p}=.54)$. Those in the top set demonstrated the most positive attitude 20.15 , the second set the next most favourable 19.47 add those in the lowest set 18.3. 
When questions relating to being shown respect or being called names were analysed separately, there were highly significant differences between the sets. Those in the lower sets agreed most strongly that they were called names with a mean of 2.71 . The mean for the middle sets was 2.82 and 2.34 in the top set. These differences were statistically significant (F $=8.6, \mathrm{df}=2,231, \mathrm{p}=.0001)$. When pupils were asked if they were shown respect for being in their mathematics set those in the top set agreed more strongly with this (mean 1.66), with a lesser response in the middle sets (1.19) the lowest scores being in the bottom set (.82). The relatively low scores for all of these responses suggests that being good at mathematics does not confer high status within school $(\mathrm{F}=4.9$, $\mathrm{df}=2,231, \mathrm{p}=.008)$.

\section{Relationships between ability grouping and pupils' perceptions of their mathematics teacher}

A composite score for pupils' perceptions of the skills of their mathematics teacher was calculated. There were no significant differences in scores relating to pupils' perceptions of their mathematics teachers in relation to being in a particular set or year group.

\section{What best predicts the different aspects of self concept?}

Multiple regression was undertaken to establish which variables best predicted mathematics self-concept, general school self-concept and general self-concept. Using a step wise multiple regression, mathematics self-esteem was found to be best predicted by the set, high, middle or

low (beta .29), perceptions of the mathematics teacher (.2) and general self-concept (beta .61). 
Together these gave a multiple $\mathrm{R}$ of .61 accounting for $37 \%$ of the variance $\left(\mathrm{R}^{2}=.37\right)(\mathrm{F}=$ $27.29, \mathrm{df}=4,188, \mathrm{p}=.0001)$.

School self-concept was best predicted by general self-concept (beta .82), set placement (beta $.24)$ and mathematics self-concept (-.199). Together these gave a multiple $\mathrm{R}$ of .81 accounting for $70 \%$ of the variance $\left(\mathrm{R}^{2}=.7\right) .(\mathrm{F}=153.35, \mathrm{df}=3.189, \mathrm{p}=.0001)$. Mathematics selfconcept was negatively related to general self-concept.

General self-concept was best predicted by school self-concept (beta .77), mathematics selfconcept (beta .27) and set (.172). Together these gave a multiple $\mathrm{R}$ of .85 accounting for $72 \%$ of the variance $\left(\mathrm{R}^{2}=.72\right)(\mathrm{F}=167.1, \mathrm{df}=3.189, \mathrm{P}=.0001)$. The lower the set the lower the general self-concept.

\section{Discussion}

The findings from the research reported here, and those from earlier research (Ireson et al., 2001) indicate that there are complex relationships between structured ability grouping and self-concept which seem to be mediated by school and teacher factors. The evidence presented above shows an overall tendency for setting to influence mathematics self concept increasingly as students progress through school and as the setting itself becomes more rigorous. Generally, the longer that pupils experience being in a low set the greater the negative effects on all aspects of their self-concept. This has considerable implications for schools when decisions are made about the ability grouping practices that will be adopted. 
While there was a relationship between set placement and pupils' attitudes towards mathematics and school, there was not in relation to perceptions of teacher skills and teacher support. This suggests that mathematics teachers played an important role in mediating some of the negative aspects of setting.

All aspects of self-concept showed an increase between years 7 and 9 decreasing in year 10 . This trend may reflect the increasing pressure that pupils find themselves under in Year 10 as they begin their General Certificate of Secondary Education (GCSE) courses and move into a phase of their education where there is a greater emphasis on examination performance. When these differences were broken down by set placement the scores for mathematics self-concept showed a rise in some classes. The greatest difference was for those in the bottom set where a substantial fall in mathematics self-concept could be seen between pupils in year 9 and 10 . School and general self-concept differed between year groups most for those in the top and bottom sets. General school self-concept initially was highest in the top sets, but as pupils progressed through school the pattern changed and it was those in the middle sets who had the highest school and general self-concepts. This seemed to be related to student perceptions that the 2nd set was 'best' in year 9. This may reflect the development of a culture as pupils progress through school which values conformity and rejects instances of individuality with those in the top and bottom sets receiving increasingly negative feedback from their peers and being designated as 'boffins' or as 'thick' (Hallam et al., submitted, a).

The study indicated considerably lower mathematics self-concept in comparison with school and general self-concept. Overall, pupils did not rate themselves highly on their potential in or 
enjoyment of mathematics. In addition, mathematics self-concept did not appear to play a major role in pupils' school status suggesting the value placed on being good at mathematics by pupils, and perhaps in the wider community is relatively low. If performance in mathematics is to be improved in the UK, the value attached to it needs to be raised.

Overall, reflecting earlier findings (Hallam et al., submitted, b), as pupils gained more experience of setting, they preferred it to mixed ability teaching, although there was considerable variation within individual classes again suggesting that teachers had a mediating role. A substantial proportion of pupils were dissatisfied with their set placement confirming earlier findings (Hallam et al., submitted, a, b). The major reason given for this was that the pupils perceived that the work was too easy. This has considerable practical implications for schools indicating as it does that pupil movement between sets needs to be made more flexible. It also suggests that many pupils may be underachieving because of inappropriate set placement. While there are obvious limitations to this study in terms of its size and focus on a single school, its confirmation of the previous findings adds weight to the proposition that if there is a genuine commitment to raising standards in the UK, pupil underachievement reinforced by setting procedures needs to be addressed.

\section{References}

BALL, S.J. (1981) Beachside Comprehensive: A case-study of secondary schooling. (Cambridge, Cambridge University Press). 
BOALER, J. (1997a) Setting, social class and the survival of the quickest, British Educational Research Journal, 23, 575-595.

BOALER, J. (1997b) When even the winners are losers: evaluating the experiences of 'top set' students, Journal of Curriculum Studies, 29, 165-182.

BOALER, J. (1997c) Experiencing school mathematics: teaching styles, sex and setting. Buckingham: Open University Press.

BOALER, J., WILIAM, D., \& BROWN, M. (2000) Experiences of ability grouping disaffection, polarisation and the construction of failure. British Educational Research Journal, 28(5), 6311-648.

DEPARTMENT FOR EDUCATION AND EMPLOYMENT (1997). Excellence in Schools. (London, HMSO).

GAMORAN, A. \& BERENDS, M. (1987). The effects of stratification in secondary school: synthesis of survey and ethnographic research. Review of Educational Research, 57, pp. 415435.

HALLAM, S. (in press) Ability grouping in schools: A literature review. London: Institute of Education, University of London 
HALLAM, S. \& TOUTOUNJI, I. (1996). What do we know about the grouping of pupils by ability? (London, Institute of Education).

HALLAM, S. IRESON, J. \& HURLEY, C. (submitted to British Journal of Educational Psychology - a) Experiences of ability grouping in the secondary school 1.: Pupils' voices

HALLAM, S. IRESON, J. \& HURLEY, C. (submitted to British Journal of Educational Psychology - b) Experiences of ability grouping in the secondary school 2: Pupil preferences and rationales

HARGREAVES, D.H. (1967) Social relations in a Secondary school. (London, Tinling).

HARLEN, W. \& MALCOLM, H. (1997). Setting and Streaming: A Research Review. (Edinburgh, Scottish Council for Research in Education).

IRESON, J. \& HALLAM, S. (1999) Raising standards: is ability grouping the answer? Oxford Review of Education, 25(3), pp. 343-358.

IRESON, J. \& HALLAM, S. (2001) Ability Grouping in Education. (London, Sage Publications) 
IRESON, J. HALLAM, S., HACK, S., CLARK, H. \& PLEWIS, I. (in press) Ability grouping in English, mathematics and science: effects on pupil attainment, Journal of Educational Research and Evaluation

IRESON, J., HALLAM, S., \& PLEWIS, I. (2001) Ability grouping in secondary schools: Effects on pupils' self-concepts, British Journal of Educational Psychology, 71, pp. 315-326.

KULIK, J. A. \& KULIK, C-L. C. (1992). Meta-analytic findings on grouping programs, Gifted Child Quarterly, 36(2), pp. 73-77.

LACEY, C. (1974). Destreaming in a pressured academic environment. In Eggleston, J. (Ed.) Contemporary Research in the Sociology of Education. (London, Methuen).

MARSH, H. W. (1990). Self Description Questionnaire II Manual. (Sydney, University of Western Sydney).

MARSH, H. W. (1991). The failure of high-ability high schools to deliver academic benefits: The importance of academic self-concept and educational aspirations. American Educational Research Journal, 28, pp. 445-480.

MARSH, H. W., CHESSOR, D., CRAVEN, R. G. \& ROCHE, L. (1995). The effects of gifted and talented program on academic self-concept: The big fish strikes again. American Educational Research Journal, 32, pp. 285-319. 
MARSH, H. W., PARKER, J. \& BARNES, J. (1985). Multidimensional adolescent selfconcepts: their relationship to age, sex and academic measures. American Educational Research Journal, 22, pp. 422-444.

MARSH, H. W. \& PEART, N. (1988). Competitive and cooperative physical fitness training programs for girls: effects on physical fitness and on multidimensional self-concepts. Journal of Sport and Exercise Psychology, 10, pp. 390-407.

MARSH, H. W., \& ROWE, K. J. (1996). The negative effects of school-average ability on academic self-concept: an application of multilevel modelling. Australian Journal of Education, 40(1), pp. 65-87.

MARSH, H. W. \& YEUNG, A. S. (1997) Coursework selection: Relations to academic selfconcept and achievement American Educational Research Journal, 34(4), pp. 691-720.

OAKES, A. (1985). Keeping Track: How Schools Structure Inequality. (New Haven, Yale University Press)

SUKHNANDEN, AND LEE. (1998). Streaming, setting and grouping by ability: a review of the literature. (Slough, National Foundation for Educational Research) 
Figure 1

Differences in aspects of self-concept as pupils' progress through school

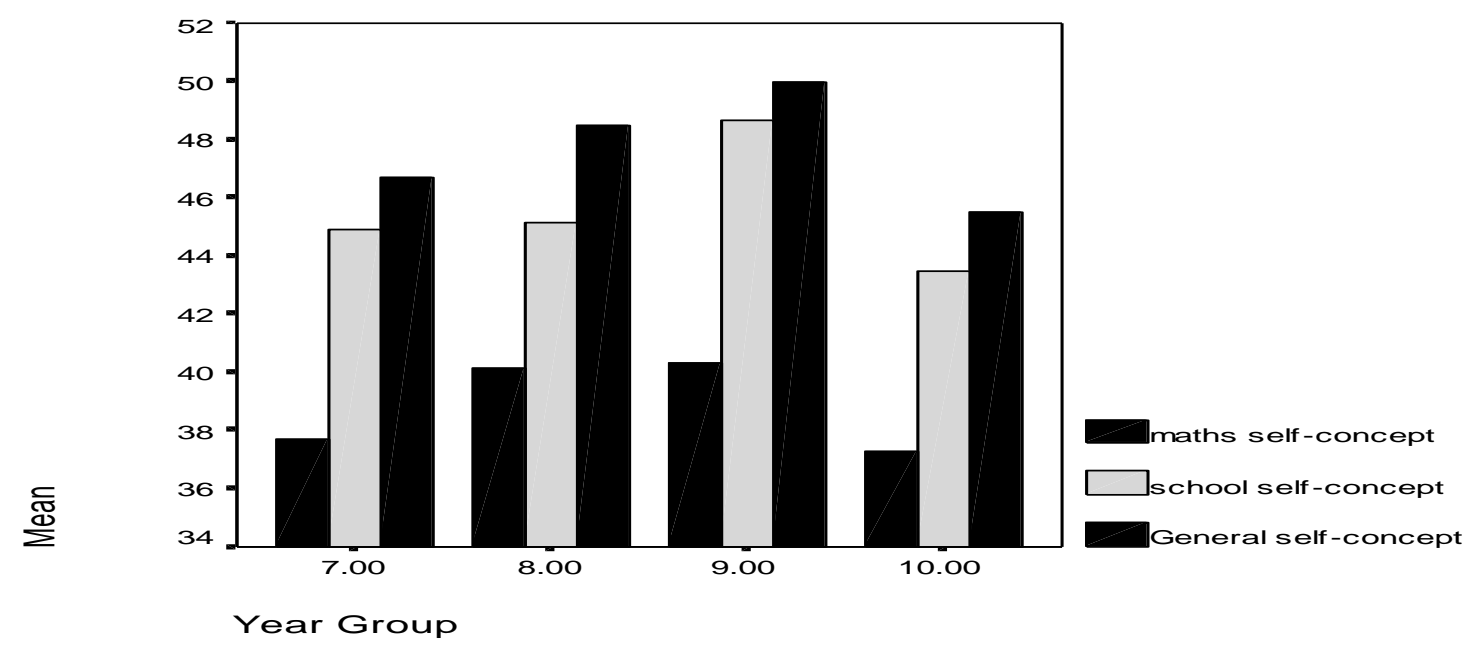


Table 1

Aspects of self-concept by set placement in Year 8

\begin{tabular}{|l|l|l|l|l|l|l|l|l|l|l|l|}
\hline & \multicolumn{2}{l|}{ Top sets } & \multicolumn{2}{l|}{$2^{\text {nd }}$ sets } & \multicolumn{2}{l|}{ Bottom sets } & F & Sig. \\
\hline & Mean & SD & Mean & SD & Mean & SD & Mean & SD & & \\
\hline $\begin{array}{l}\text { Mathematics } \\
\text { self-concept }\end{array}$ & $\mathbf{4 4 . 2}$ & 5.7 & $\mathbf{4 2}$ & 7.6 & $\mathbf{3 7 . 3}$ & 8.45 & $\mathbf{3 7 . 9}$ & 8.44 & & NS \\
\hline $\begin{array}{l}\text { General school } \\
\text { concept }\end{array}$ & $\mathbf{5 3 . 4}$ & 5.3 & $\mathbf{4 5 . 7 5}$ & 6.6 & $\mathbf{4 2 . 2 9}$ & 8.88 & $\mathbf{4 1 . 6 9}$ & 9.29 & 5.43 & .002 \\
\hline $\begin{array}{l}\text { General self- } \\
\text { concept }\end{array}$ & $\mathbf{5 1 . 5}$ & 5.5 & $\mathbf{4 8 . 8 4}$ & 7.4 & $\mathbf{4 7 . 0 6}$ & 6.36 & $\mathbf{4 7 . 5 4}$ & 6.6 & & NS \\
\hline
\end{tabular}


Table 2

Aspects of self-concept by set placement in Year 9

\begin{tabular}{|c|c|c|c|c|c|c|c|c|c|c|}
\hline & \multicolumn{2}{|c|}{ Top sets } & \multicolumn{2}{|c|}{$2^{\text {nd }}$ sets } & \multicolumn{2}{|c|}{$3^{\text {rd }}$ sets } & \multicolumn{2}{|c|}{ Bottom sets } & \multirow[t]{2}{*}{$\mathrm{F}$} & \multirow[t]{2}{*}{ Sig. } \\
\hline & Mean & SD & Mean & SD & Mean & SD & Mean & SD & & \\
\hline $\begin{array}{l}\text { Mathematics } \\
\text { self-concept }\end{array}$ & 44.7 & $\begin{array}{l}5.9 \\
6\end{array}$ & 38.94 & 7.33 & 34.64 & 6.05 & 39.57 & 3.64 & 6.85 & .001 \\
\hline $\begin{array}{l}\text { General school } \\
\text { concept }\end{array}$ & 53.6 & 4.1 & 48.7 & 7.7 & 45.9 & 4.7 & 38 & 3.4 & 15.37 & .0001 \\
\hline $\begin{array}{l}\text { General self- } \\
\text { concept }\end{array}$ & 53.9 & $\begin{array}{l}3.4 \\
5\end{array}$ & 49.7 & 8.16 & 45.9 & 3.42 & 45.29 & 6.37 & 6.89 & .001 \\
\hline
\end{tabular}


Table 3

Aspects of self-concept by set placement in Year 10

\begin{tabular}{|l|l|l|l|l|l|l|l|l|l|l|l|l|l|}
\hline & \multicolumn{2}{|l|}{ Top sets } & \multicolumn{2}{l|}{$2^{\text {nd }}$ sets } & \multicolumn{3}{l|}{$3^{\text {rd }}$ sets } & \multicolumn{2}{l|}{$4^{\text {th }}$ sets } & \multicolumn{2}{l|}{ Bottom sets } & & \\
\hline & Mean & SD & Mean & SD & Mean & SD & Mean & SD & Mean & SD & F & Sig \\
\hline $\begin{array}{l}\text { Mathematics } \\
\text { self-concept }\end{array}$ & $\mathbf{4 2 . 7}$ & 5.6 & $\mathbf{3 9 . 2}$ & 7.2 & $\mathbf{3 7 . 7}$ & 5.7 & $\mathbf{3 5 . 5}$ & 6.7 & $\mathbf{2 8 . 1}$ & 6.8 & 6.4 & .0001 \\
\hline $\begin{array}{l}\text { General } \\
\text { school } \\
\text { concept }\end{array}$ & $\mathbf{4 7 . 2}$ & 3.6 & $\mathbf{4 8 . 2}$ & 5.8 & $\mathbf{4 3 . 8}$ & 6.9 & $\mathbf{3 5 . 3}$ & 8.7 & $\mathbf{3 5 . 4}$ & 7.8 & 8.9 & .0001 \\
\hline $\begin{array}{l}\text { General self- } \\
\text { concept }\end{array}$ & $\mathbf{4 6 . 9}$ & 9 & $\mathbf{5 0 . 5}$ & 4.76 & $\mathbf{4 5 . 9}$ & 6.5 & $\mathbf{4 1 . 5}$ & 9.9 & $\mathbf{3 7 . 4 3}$ & 12.16 & 3.87 & .008 \\
\hline
\end{tabular}


Table 4

Pupils perceptions of the best method of grouping

\begin{tabular}{|l|l|l|l|l|l|l|l|}
\hline $\begin{array}{l}\text { Year } \\
\text { group }\end{array}$ & $\begin{array}{l}\text { Mixed } \\
\text { ability }\end{array}$ & Setting & Streaming & Banding & Other & $\begin{array}{l}\text { Don't } \\
\text { know }\end{array}$ & \\
\hline Year 7 & $38 \%$ & $37 \%$ & $5 \%$ & $5 \%$ & $2 \%$ & $13 \%$ & $\mathrm{x}^{2}=49.6, \mathrm{df}=5, \mathrm{p}=.0001$ \\
\hline Year 8 & $17 \%$ & $63 \%$ & $3 \%$ & $2 \%$ & $2 \%$ & $13 \%$ & $\mathrm{x}^{2}=104.4, \mathrm{df}=5, \mathrm{p}=.0001$ \\
\hline Year 9 & $7 \%$ & $79 \%$ & $2 \%$ & $4 \%$ & $4 \%$ & $5 \%$ & $\mathrm{x}^{2}=150.4, \mathrm{df}=5, \mathrm{p}=.0001$ \\
\hline Year 10 & $5 \%$ & $83 \%$ & & $3 \%$ & & $9 \%$ & $\mathrm{x}^{2}=103.5, \mathrm{df}=3, \mathrm{P}=.0001$ \\
\hline Total & $17 \%$ & $65 \%$ & $3 \%$ & $3 \%$ & $2 \%$ & $10 \%$ & $\mathrm{x}^{2}=417.1, \mathrm{df}=6, \mathrm{p}=.0001$ \\
\hline
\end{tabular}




\section{Table 5}

Percentage preferences for different types of grouping by set placement and year group

\begin{tabular}{|l|l|l|l|l|l|l|}
\hline & $\begin{array}{l}\text { Mixed } \\
\text { ability }\end{array}$ & Setting & Streaming & Banding & Other & $\begin{array}{l}\text { Don't } \\
\text { know }\end{array}$ \\
\hline Year 8 set 1 & 20 & 80 & & & & \\
\hline Year 8 set 2 & 5 & 90 & 5 & & & \\
\hline Year 8 set 3 & 23 & 59 & & & 6 & 12 \\
\hline Year 8 set 4 & 23 & 15 & 8 & 8 & & 46 \\
\hline Year 9 set 1 & & 81 & & 5 & 5 & 9 \\
\hline Year 9 set 2 & 6 & 82 & & 6 & & 6 \\
\hline Year 9 set 3 & 18 & 82 & & & & \\
\hline Year 9 set 4 & 14 & 57 & 14 & & 14 & \\
\hline Year 10 set 1 & & 90 & & & & 10 \\
\hline Year 10 set 2 & & 93 & & 7 & & \\
\hline Year 10 set 3 & 7 & 73 & & & & 20 \\
\hline Year 10 set 4 & 10 & 70 & & 10 & & 10 \\
\hline Year 10 set 5 & 12 & 88 & & & & \\
\hline
\end{tabular}


Table 6

Pupils perceptions of the best set by year group

\begin{tabular}{|l|l|l|l|l|l|l|}
\hline $\begin{array}{l}\text { Year } \\
\text { group }\end{array}$ & Set 1 & Set 2 & $\begin{array}{l}\text { Bottom } \\
\text { sets }\end{array}$ & $\begin{array}{l}\text { Set where work is } \\
\text { appropriate }\end{array}$ & No response & \\
\hline Year 7 & $7 \%$ & $2 \%$ & $4 \%$ & $3 \%$ & $85 \%$ & \\
\hline Year 8 & $68 \%$ & $15 \%$ & $5 \%$ & $8 \%$ & $3 \%$ & $\mathrm{x}^{2}=90, \mathrm{df}=4, \mathrm{p}=.0001$ \\
\hline Year 9 & $55 \%$ & $21 \%$ & $13 \%$ & $7 \%$ & $4 \%$ & $\mathrm{x}^{2}=88, \mathrm{df}=6, \mathrm{p}=.0001$ \\
\hline Year 10 & $60 \%$ & $14 \%$ & $9 \%$ & & $17 \%$ & $\mathrm{x}^{2}=39.5, \mathrm{df}=3, \mathrm{p}=.0001$ \\
\hline Overall & $48 \%$ & $13 \%$ & $7 \%$ & $4.7 \%$ & $28 \%$ & $\mathrm{x}^{2}=373.4, \mathrm{df}=7, \mathrm{p}=.0001$ \\
\hline
\end{tabular}

